\title{
Adsorption Characteristics of Magnesium-Modified Bentonite Clay with Respect to Acid Blue 129 in Aqueous Media
}

\author{
Sajjad Hussain ${ }^{1 *}$, Zia Ullah², Saima Gul³, Rozina Khattak³, \\ Nida Kazmi², Fozia Rehman', Sabir Khan', Khalid Ahmad', \\ Mohammad Imad ${ }^{1}$, Adnan Khan ${ }^{2}$
}

${ }^{1}$ Faculty of Materials and Chemical Engineering, GIK Institute of Engineering Sciences and Technology Topi, 23460, KPK, Pakistan

${ }^{2}$ Institute of Chemical Sciences, University of Peshawar, 25120, KPK, Pakistan

${ }^{3}$ Department of Biochemistry, Shaheed Benazir Bhutto Women's University, Peshawar, KPK, Pakistan

${ }^{4}$ Interdisciplinary Research Center In Biomedical Materials (IRCBM), COMSAT Institute, Lahore, Pakistan

${ }^{5}$ Institute of Chemistry, State University of Campinas, CEP 13083-970 Campinas, SP, Brazil

Received: 13 February 2016

Accepted: 20 March 2016

\begin{abstract}
Locally available bentonite clay has been modified by magnesium and used to eliminate acid blue 129 from aqueous solutions. The adsorption was studied under different experimental conditions such as dye concentrations, temperature, and shaking time. The adsorption of the dye increased with time and followed the pseudo-first-order kinetic with rate constant " $k$ " $0.126 \mathrm{~min}^{-1}$ at $283 \mathrm{~K}$. Thermodynamic parameters such as $\Delta H^{\circ}, \Delta S^{\circ}$, and $\Delta G^{\circ}$ were calculated from the slope and intercept of the linear plots of $\ln K$ against $1 / T$. Analysis of adsorption results obtained at temperatures of 283, 293, 303, and $313 \mathrm{~K}$ showed that the adsorption pattern on bentonite seems to follow Langmuir and Freundlih. The increase in temperature reduces adsorption capacity by magnesium-modified bentonite due to the enhancement of the desorption step in the mechanism. The activation energy of the adsorption process was found to be $3.55 \mathrm{~kJ} \mathrm{~mol}^{-1}$. The Mg-bentonite showed better adsorption than $\mathrm{Ba}$ and Al-bentonite. Our study reveals that abundantly available local clay may be used to eliminate dyes from aqueous solutions.
\end{abstract}

Keywords: acid blue, clay, adsorption, isotherms, kinetics, bentonite

*e-mail: sajjadchemist@yahoo.com 


\section{Introduction}

Dyes and pigments are used in many industries to color their products. The effluents discharged by the dye industry are highly colored and are a major cause of environmental pollution [1]. Dyes are resistant to light, oxidizing agents, and heat due to their chemical nature, and are also biologically non-degradable and cannot be easily decolorized once released into an aquatic environment [2$3]$. The strong colors imparted by the dyes cause aesthetic and ecological problems to aquatic ecosystems [4-6].

In particular, the presence of dye-containing effluents into a water environment may be carcinogenic and mutagenic and may cause intense damage to human beings, including the reproductive system, liver, brain, central nervous system, and dysfunction of kidneys [7].

Wastewater treatment methods such as coagulation [8], ozonation and filtration [9], oxidation, [10], sedimentation, flotation, [11] reverse osmosis, nano filtration [12], electrochemical oxidation [13], and photo-electrochemical oxidation [14] are used to treat water-containing dyes from the textile industries, but all these processes must be considered for economic reasons. Adsorption has proven to be very efficient at removing dye pollutants from effluent $[4,15-16]$. The interaction of wastewater molecules to the surface of the adsorbent may be expressed in terms of both adsorptive characteristics and physical properties of the adsorbent [17]. The acid dyes can be successfully removed with activated carbon [18] and with sepiolite [19], and these processes have been carried out by many researchers. It has been found that due to high adsorption capacity, high surface area, micro porous structure, and the high degree of surface reactivity of activated carbon, it is widely used, but there are some problems with its use such as being expensive in nature due to the operational costs of activated carbon. The researchers are looking for cheaper, easily available materials for dye adsorption [20-21]. Various types of clay sepiolite [19], zeolite [22], montmorillonite [23-24], smectite [25], and bentonite [26] may be used as alternative low-cost adsorbents for treating dye effluents. Specific surface area, high chemical and mechanical stability, and various structural and surface properties make the clays widely useful. The sorption ability of a clay is usually determined by its chemical and pore structure.

Bentonite (i.e., montmorillonite clay) is normally characterized by one aluminum (Al) octahedral sheet placed between two silicon ( $\mathrm{Si}$ ) tetrahedral sheets. The negative surface charge on the bentonite is produced due to isomorphous substitution of $\mathrm{A}^{3+}$ for $\mathrm{Si}^{4+}$ in the tetrahedral layer and $\mathrm{Mg}^{2+}$ for $\mathrm{Al}^{3+}$ in the octahedral layer. The exchangeable cations $\left(\mathrm{Ba}^{2+}, \mathrm{Mg}^{2+}\right.$, etc. $)$ imbalance the charge at the bentonite surface and both $\mathrm{Ba}^{2+}$ and $\mathrm{Mg}^{2+}$ are heavily hydrated in the presence of water, making the Bentonite's surface hydrophilic in nature [27].

The specific surface area of the clay samples can be greatly increased by acid activation and therefore acidactivated clays can be used effectively as decolorizing agents for various industries [28]. The surface properties of bentonite clay can also be greatly modified with simple ion-exchange reactions by using a cations exchanger like $\mathrm{H}^{+}, \mathrm{Mg}^{2+}$, and $\mathrm{Ba}^{2+}$. This is favored by van der Waals interaction between the cations and clay. These cations occupy the exchange sites of bentonite clay and hence the surface area is increased. This kind of cationic bentonite has been used extensively for a wide variety of environmental applications [29]. This work aims to investigate the effectiveness of magnesium-modified bentonite toward acid blue 129 removal. Adsorption isotherm techniques are used to examine the adsorption capacities of dye. The rate constants and activation energy of adsorption process were used to calculate kinetics and thermodynamic parameters. Langmuir and Freundlich equations are applied to the experimental data in order to determine the isotherm that gives the best correlation to the experimental data.

\section{Material and Methods}

\section{Material Preparation and Chemicals}

The bentonite clay sample was collected from Nowshera city KPK, Pakistan. The Clay sample was ground into powder manually and the wet sedimentation process was used to get refined particles of the clay. Initially $50 \mathrm{~g}$ of raw bentonite was refluxed with 1 molar of hydrochloric acid for two hours in a round-bottomed flask at $80^{\circ} \mathrm{C}$. The slurry was air cooled and washed with doubly distilled water and then the clay was dried in an oven at $120^{\circ} \mathrm{C}$. After complete drying, $50 \mathrm{~g}$ of clay was added to 1 molar of $\mathrm{MgCl}_{2}$ solution and stirred for 24 hours on a magnetic stirrer. It was then air cooled, dried, and washed with doubly distilled water four times to eliminate free salts, and finally dried in an oven at $150^{\circ} \mathrm{C}$. Acid Blue 129 from Aldrich Chemicals Pakistan (and used as received) was employed as a pollutant. All other chemicals - $\mathrm{HCl}, \mathrm{NaOH}$, and $\mathrm{MgCl}_{2}$ - were obtained from Aldrich.

\section{Characterization of Samples}

The textural structure of the clay sample was measured by $\mathrm{N}_{2}$ adsorption at NOVA 2200e Quanta Chrome, USA. All samples were degassed at $373 \mathrm{~K}$ for $2 \mathrm{~h}$, prior to the adsorption experiments. The BET surface area and pore volume were obtained by applying the Langmuir method. Microstructure and surface morphology of the adsorbent samples were characterized by a JEOL 5910 field emission scanning electron microscope (SEM) with an accelerating voltage $15.0 \mathrm{kV}$ at $1,500 \mathrm{x}$ magnification.

\section{Adsorption Tests}

The adsorption tests were conducted by batch experiments. In each assay, $0.1 \mathrm{~g}$ of modified magnesium clay and $30 \mathrm{ml}$ of solution with $4 \times 10^{-5} \mathrm{~mol}$ $\mathrm{L}^{-1}$ concentration of $\mathrm{AB} 129$ (Fig. 1.) filled a bottle and 
<smiles>Cc1cc(C)c(Nc2cc(S(=O)(=O)O[AlH2])c(N)c3c2C(=O)c2ccccc2C3=O)c(C)c1</smiles>

Fig. 1. Chemical structure of dye AB129.

were put in a shaker at $120 \mathrm{rpm}$. The samples were taken out, filtered, and analyzed (using a Shimadzu UV-160 A) at $\lambda \max 629 \mathrm{~nm}$, and the amount of dye adsorbed $\left(\mathrm{q}_{\mathrm{e}}, \mathrm{mol} \mathrm{g}^{-1}\right)$ was calculated accordingly [30-31].

\section{Results and Discussion}

\section{Characterization of Mag-Bentonite}

The surface area was calculated using Langmuir method and revealed that $\mathrm{Mg}-, \mathrm{Ba}-$, and $\mathrm{Al}$-modified clay are, respectively, $1310.03,1010.22$, and $878.77 \mathrm{~m}^{2} \mathrm{~g}^{-1}$. Figs S1, S2, and S3 of supplementary information show the SEM images of the Mg-, Ba-, and Al-bentonite clay, respectively, and it can be observed that clay constituted of hollowed spheres of different sizes and some other agglomerated unshaped fragments can also be seen in S1, but large particles can be observed in S2 and S3, which may cause a reduction in adsorption of dye molecules. Elemental analysis is presented in Figs S4, S5, and S6

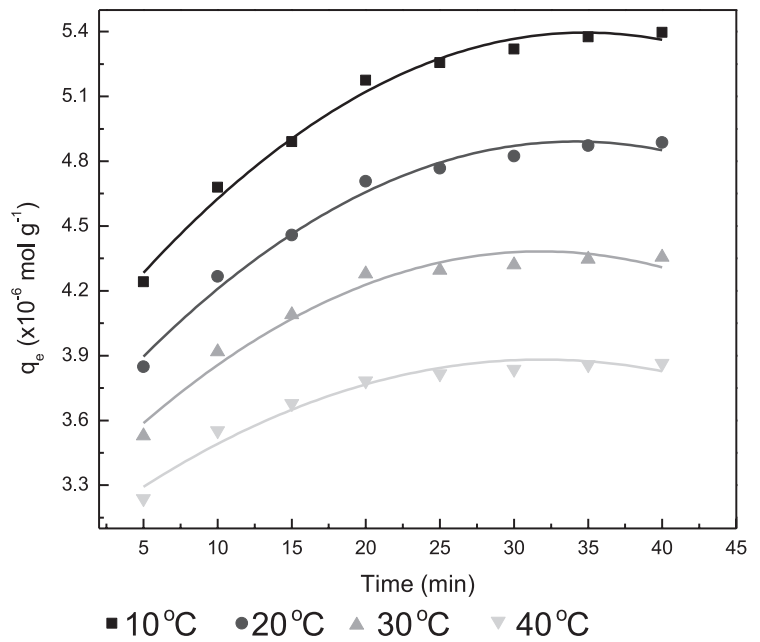

Fig. 2. Time versus amount adsorbed $\left(\mathrm{q}_{\mathrm{e}}\right)$ plot of $\mathrm{AB} 129$ $(\mathrm{pH}=3.0)$ adsorption by $\mathrm{Mg}$-bentonite, $(0.1 \mathrm{~g} / 30 \mathrm{~mL})$ at $10^{\circ} \mathrm{C}$, $20^{\circ} \mathrm{C}, 30^{\circ} \mathrm{C}$, and $40^{\circ} \mathrm{C}$. of supplementary for $\mathrm{Mg}$-, Ba-, and $\mathrm{Al}$-bentonite, and the presence of $\mathrm{O}_{2}, \mathrm{Si}, \mathrm{Al}, \mathrm{Mg}, \mathrm{Ba}, \mathrm{Fe}$, and $\mathrm{Cl}$ may be observed in these EDX spectra.

\section{Batch Adsorption Studies}

\section{Effect of Contact Time}

We studied the adsorption of acid blue 129 ions on $\mathrm{Mg}$-bentonite clay from aqueous solution at different temperatures (Fig. 2). The results make it clear that the adsorption on Mg-bentonite clay increases with time. Furthermore, the dye uptake by activated Mg-Bentonite clay was rapid initially up to 25 minutes, followed by a continued rise up to 40 minutes, and $5.397 \times 10^{-6} \mathrm{~mol} \mathrm{~g}^{-1}$ of $\mathrm{AB} 129$ was adsorbed on $\mathrm{Mg}$-Bentonite at $10^{\circ} \mathrm{C}$. The 40 minutes were taken as equilibrium time and used for further study. The initial rapid uptake from solution was due to extra cellular bonding and the slow sorption phase likely resulted from intracellular binding.

\section{Effect of Temperature}

Fig. 3 also shows the effect of temperature on the adsorption of AB129 ions on Mg-bentonite clay. You can observe in Fig. 2 that the amount of adsorption decreases from $5.400 \times 10^{-6} \mathrm{~mol} \mathrm{~g}^{-1}$ to $3.864 \times 10^{-6} \mathrm{~mol} \mathrm{~g}^{-1}$ with the rise in temperature from 10 to $40^{\circ} \mathrm{C}$, which means that $\mathrm{AB} 129$ ion adsorption from aqueous solution is more practical at low temperatures. The data in Table 1 also showed that the adsorption capacity of Mg-bentonite clay decreases with the increase in temperature. This is due to the dye molecules escaping from solid phase to bulk phase when there is an increase in temperature of the solution.

\section{Effect of Initial Dyes Concentration}

The influence of the initial concentration of AB129 in the solutions on the rate of adsorption onto Mg-bentonite was investigated at various concentrations at $\mathrm{pH} 3$.

It is clear from Fig. 3 that the adsorption of AB129 increases from 15.15 to $67.92 \times 10^{-5} \mathrm{~mol} \mathrm{~g}^{-1}$ as the concentration increases from 1.0 to $6.0 \times 10^{-7} \mathrm{~mol} \mathrm{~L}^{-1}$ in $40 \mathrm{~min}$ of treatment at constant $\mathrm{pH}$. This is due to the greater availability of AB129 ions to the active sites of the activated clay. It is clear from Fig. 3 that at low concentrations most of the AB129 ions are adsorbed. At higher concentration there is no significant effect on the AB129 ions due to the saturation of the surface. This indicates that the initial dye concentration plays an important role in the adsorption capacities of AB129 onto Mg-bentonite clay.

\section{Kinetics of Adsorption}

In order to investigate the kinetics of adsorption of acid blue 129 on Mg-bentonite clay, the Lagergren equation (Eq. 1) was found to apply to the adsorption data: 


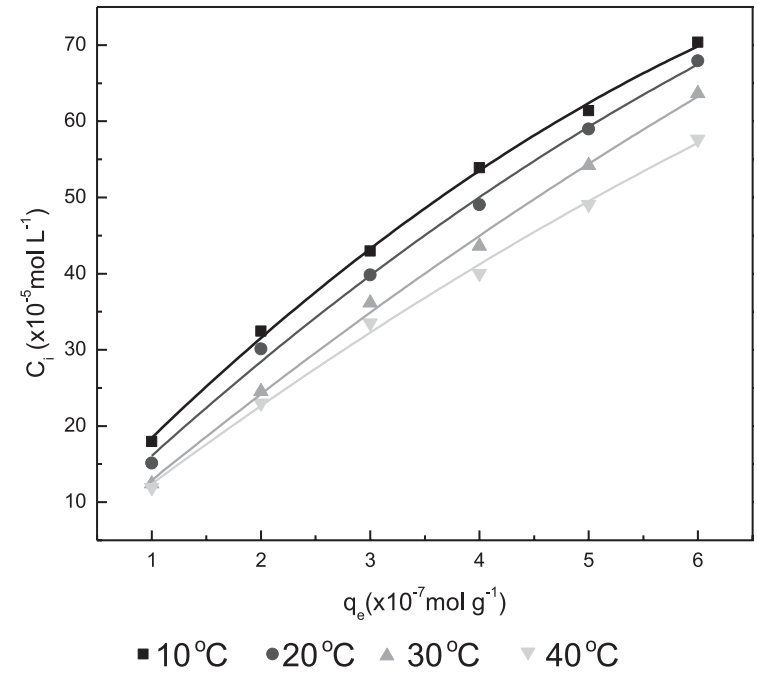

Fig. 3. Effect of initial acid blue 129 concentration for the adsorption by $\mathrm{Mg}$-bentonite clay $(0.1 \mathrm{~g} / 30 \mathrm{~mL})$ at $\mathrm{pH} 3.0$ and $10^{\circ} \mathrm{C}, 20^{\circ} \mathrm{C}, 30^{\circ} \mathrm{C}$, and $40^{\circ} \mathrm{C}$.

$$
\log \left(q_{e}-q_{t}\right)=\log q_{e}-\frac{k_{1} t}{2.303}
$$

...where $\mathrm{q}_{\mathrm{e}}$ and $\mathrm{q}_{\mathrm{t}}$ are the amount of AB129 (mol g-1) adsorbed at equilibrium and at time $\mathrm{t}$, respectively, and $\mathrm{k}_{1}$ is overall rate constant. Straight lines were obtained by plotting $\log \left(\mathrm{q}_{\mathrm{e}}-\mathrm{q}_{\mathrm{t}}\right)$ against $\mathrm{t}$, as shown in Fig. 4. These straight lines indicate that the adsorption process follows first-order kinetics. The values of rate constant $\mathrm{k}$ were calculated from the slopes of straight lines of Fig. 4 and are given in Table 1, which increases with increases in temperature. The activation energy Ea for adsorption was calculated using the Arrhenius equation and was found to be $3.550 \mathrm{~kJ} \mathrm{~mol}^{-1}$.

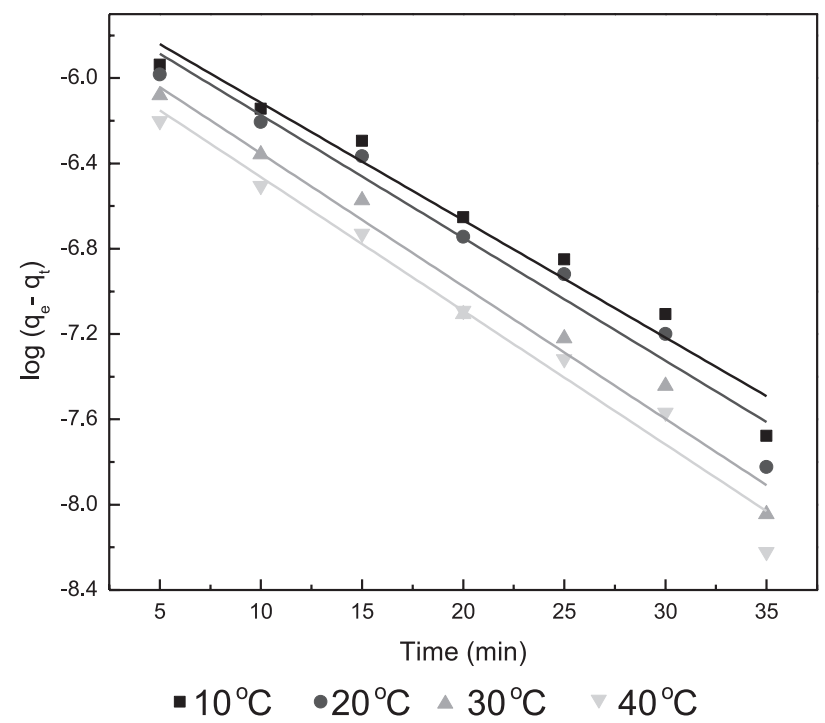

Fig. 4. Time versus $\log \left(\mathrm{q}_{\mathrm{o}}-\mathrm{q}\right)$ plot of $\mathrm{AB} 129(\mathrm{pH}=3.0)$ adsorption by $\mathrm{Mg}$-bentonite $(0.1 \mathrm{~g} / 30 \mathrm{~mL})$ at $10^{\circ} \mathrm{C}, 20^{\circ} \mathrm{C}, 30^{\circ} \mathrm{C}$, and $40^{\circ} \mathrm{C}$.
Table 1. Rate constant and activation energy parameters for the adsorption of AB129 on Mg-bentonite at different temperatures.

\begin{tabular}{|c|c|c|c|c|c|}
\hline $\begin{array}{c}T \\
\left({ }^{\circ} \mathrm{C}\right)\end{array}$ & $\begin{array}{c}q_{e} \\
\left(\mathrm{~mol} \mathrm{~g}^{-1}\right)\end{array}$ & $\begin{array}{c}k_{1} \\
\left(\mathrm{~min}^{-1}\right)\end{array}$ & $R^{2}$ & $\begin{array}{c}1 / \mathrm{T} \\
\left(\times 10^{-3} \mathrm{~K}^{-1}\right)\end{array}$ & $\begin{array}{c}\mathrm{Ea} \\
\left(\mathrm{kJ} \mathrm{mol}^{-1}\right)\end{array}$ \\
\cline { 1 - 4 } 10 & 5.397 & 0.126 & 0.9961 & 3.53 & \\
\cline { 1 - 4 } 20 & 4.887 & 0.132 & 0.9615 & 3.41 & \multirow{2}{*}{3.550} \\
\cline { 1 - 4 } 30 & 4.356 & 0.143 & 0.9734 & 3.3 & \\
\cline { 1 - 4 } 40 & 3.864 & 0.144 & 0.9743 & 3.19 & \\
\hline
\end{tabular}

\section{Adsorption Equilibrium}

The equilibrium adsorption study of $\mathrm{AB} 129$ on $\mathrm{Mg}$ bentonite clay was evaluated at $10^{\circ} \mathrm{C}, 20^{\circ} \mathrm{C}, 30^{\circ} \mathrm{C}$, and $40^{\circ} \mathrm{C}$. Two isotherm equations were applied since the adsorption isotherm plays a vital role in studying the nature of the adsorption system. The data of this study is evaluated by applying the Langmuir and Freundlich isotherms. The linear form of Langmuir (Eq. 2) was applied to the adsorption data:

$$
\frac{C_{e}}{q_{e}}=\frac{1}{K_{1} X_{m}}+\frac{C_{e}}{X_{m}}
$$

...where $\mathrm{C}_{\mathrm{e}}$ is the equilibrium concentration $(\mathrm{M}), \mathrm{q}_{\mathrm{e}}$ is the amount $\left(\mathrm{mol} \mathrm{g}^{-1}\right)$ of AB129 adsorbed, and $\mathrm{X}_{\mathrm{m}}$ and $\mathrm{K}_{1}$ are Langmuir constants that represent adsorption capacity $\left(\mathrm{mol} \mathrm{g}^{-1}\right)$ and energy of adsorption ( $\left.\mathrm{mol} \mathrm{g}^{-1}\right)$, respectively. Fig. $5 \mathrm{C}_{\mathrm{e}} / \mathrm{q}_{\mathrm{e}}$ against $\mathrm{C}_{\mathrm{e}}$ indicate the applicability of the Langmuir adsorption isotherm, consequently the formation of the monolayer surface of the adsorbate on the surface of the adsorbent. Langmuir constant $\mathrm{X}_{\mathrm{m}}$ (adsorption capacity) and $\mathrm{K}_{1}$ (binding energy constant of adsorption or energy of

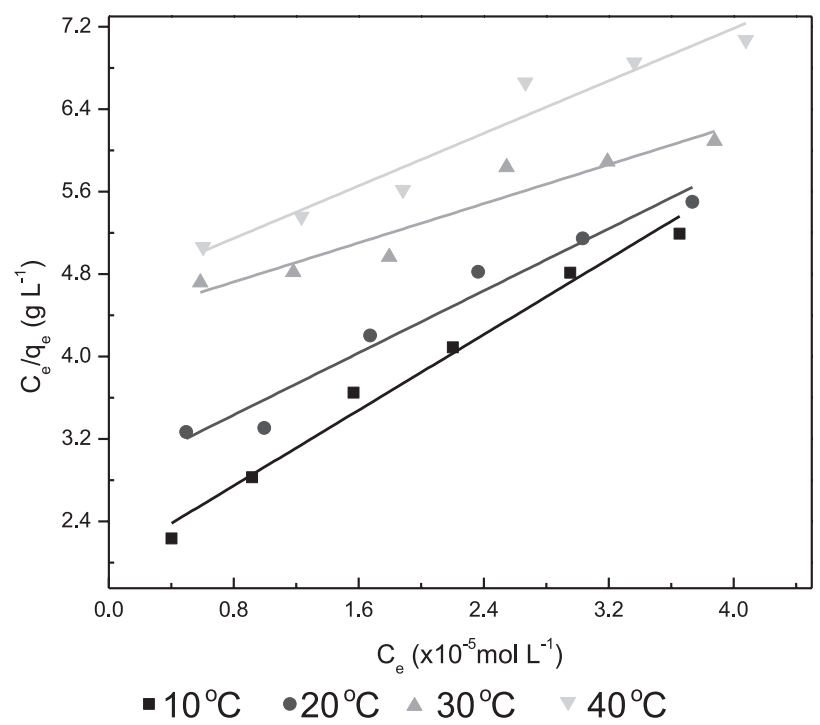

Fig. 5. Langmuir adsorption isotherms for adsorption of acid blue 129 over $\mathrm{Mg}$-bentonite clay $(0.1 \mathrm{~g} / 30 \mathrm{~mL})$ at $\mathrm{pH} 3.0$ and $10^{\circ} \mathrm{C}, 20^{\circ} \mathrm{C}, 30^{\circ} \mathrm{C}$, and $40^{\circ} \mathrm{C}$. 
Table 2. Isotherm parameters for the adsorption of AB129 on Mg-bentonite at different temperatures.

\begin{tabular}{|c|c|c|c|c|c|c|c|}
\hline & \multicolumn{3}{|c|}{ Langmuir constant } & \multicolumn{3}{c|}{ Freundlich constant } \\
\hline$T\left({ }^{\circ} \mathrm{C}\right)$ & $X m_{1}\left(x 10^{-5} \mathrm{~mol} \mathrm{~g}^{-1}\right)$ & $K_{I}\left(x 10^{4} \mathrm{~mol} \mathrm{~L}^{-1}\right)$ & $R_{L}$ & $R^{2}$ & $1 / n\left(g L^{-1}\right)$ & $K\left(x \mu m o l g^{-1}\right)$ & $R^{2}$ \\
\hline 10 & 1.215 & 4.2092 & 0.70 & 0.9913 & 0.411 & 1.603 & 0.9946 \\
\hline 20 & 1.489 & 2.3405 & 0.81 & 0.9592 & 0.436 & 1.393 & 0.9838 \\
\hline 30 & 2.350 & 0.9595 & 0.51 & 0.9019 & 0.509 & 1.030 & 0.9778 \\
\hline 40 & 1.653 & 1.3504 & 0.88 & 0.9404 & 0.479 & 1.018 & 0.9925 \\
\hline
\end{tabular}

adsorption) were calculated from the slopes and intercepts of plots of $\mathrm{C}_{\mathrm{e}} / \mathrm{q}_{\mathrm{e}}$ against $\mathrm{C}_{\mathrm{e}}$, respectively, and are given in Table 2.

The Langmuir isotherm also reveals that the adsorption of AB129 dye is feasible onto Mg-bentonite based on separation factor (dimensionless constant) RL which is given by the following equation:

$$
\mathrm{R}_{\mathrm{L}}=1 /\left(1+\mathrm{K}_{\mathrm{a}} \mathrm{C}_{\mathrm{o}}\right)
$$

Adsorption of any contaminant is regarded as favorable if $\mathrm{RL}$ values follow $0<\mathrm{R}_{\mathrm{L}}<1$, whereas $\mathrm{R}_{\mathrm{L}}>1$ (unfavorable), $\mathrm{R}_{\mathrm{L}}=1$ (linear), and $\mathrm{R}_{\mathrm{L}}=0$ (irreversible). An $R_{L}$ value less than 1 shows that adsorption of AB129 is favorable onto Mg-bentonite (Fig. 5).

The Freundlich isotherm is an empirical equation employed to describe the heterogeneous system. The linear form of Freundlich isotherm (Eq. 4) was also applied to the adsorption data of AB129 ions as given in Table 2.

$$
\ln \frac{x}{m}=\ln K+\frac{1}{n} \ln C_{e}
$$

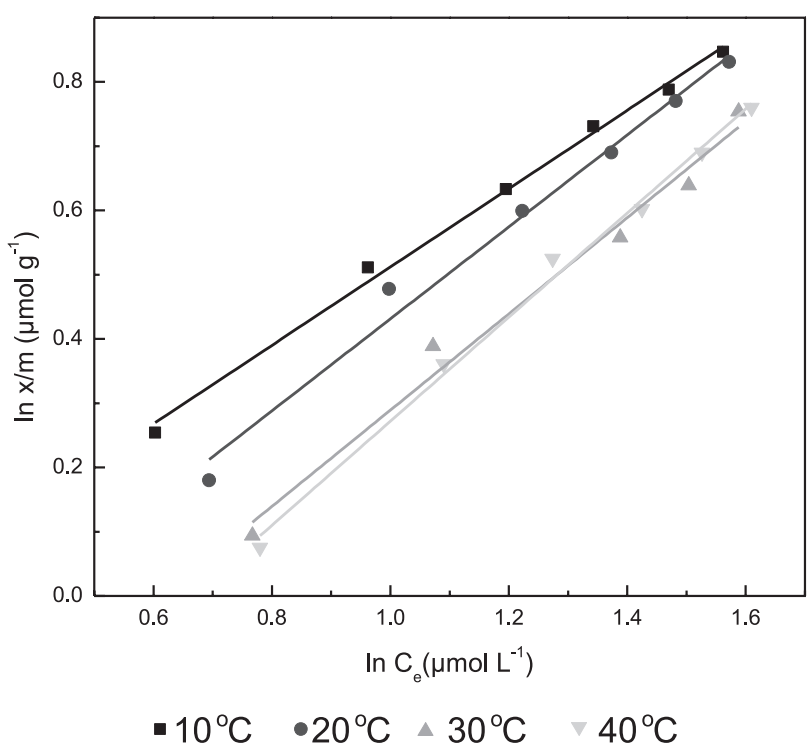

Fig. 6. Freundlich adsorption isotherms for adsorption of acid blue 129 over $\mathrm{Mg}$-bentonite $(0.1 \mathrm{~g} / 30 \mathrm{~mL})$ at $\mathrm{pH} 3.0$ and $10^{\circ} \mathrm{C}$, $20^{\circ} \mathrm{C}, 30^{\circ} \mathrm{C}$, and $40^{\circ} \mathrm{C}$. ...where $\mathrm{K}\left(\mathrm{mol} \mathrm{g}^{-1}\right)$ and $1 / \mathrm{n}\left(\mathrm{g} \mathrm{L}^{-1}\right)$ are Freundlich constants, indicating adsorption capacity and adsorption intensity, respectively. Fig. 6 shows the Freundlich profile and the values are demonstrated in Table 2. This isotherm fits better than the Langmuir isotherm $\left(R_{2}>0.994\right)$ to the adsorption data. As the values of $1 / \mathrm{n}$ increase with increasing temperature, it indicates favorable adsorption at lower temperatures. The values of $1 / \mathrm{n}$ indicate the formation of a relatively stronger bond between adsorbate and adsorbent as temperature decreases. When the values of $\mathrm{K}$ and $1 / \mathrm{n}$ (Freundlich constant) were compared at all the temperatures under study, the results show that higher values of $1 / \mathrm{n}$ and lower values of $\mathrm{K}$ were obtained at higher temperatures.

\section{Adsorption Thermodynamic}

The influence of temperature on AB129 adsorption is further explained by thermodynamic parameters. Various thermodynamic parameters such as $\Delta \mathrm{G}^{\circ}, \Delta \mathrm{H}^{\circ}$, and $\Delta \mathrm{S}^{\circ}$ of AB129 adsorption were calculated from Langmuir's binding constant $\mathrm{K}_{1}$ by using equations 5 and 6 . The values of $\Delta \mathrm{H}^{\circ}$ and $\Delta \mathrm{S}^{\circ}$ were calculated from the slope and intercept, respectively, of linear variation of $\ln \mathrm{K}_{1}$ versus 1/T (Fig. 7) using Equation 7:

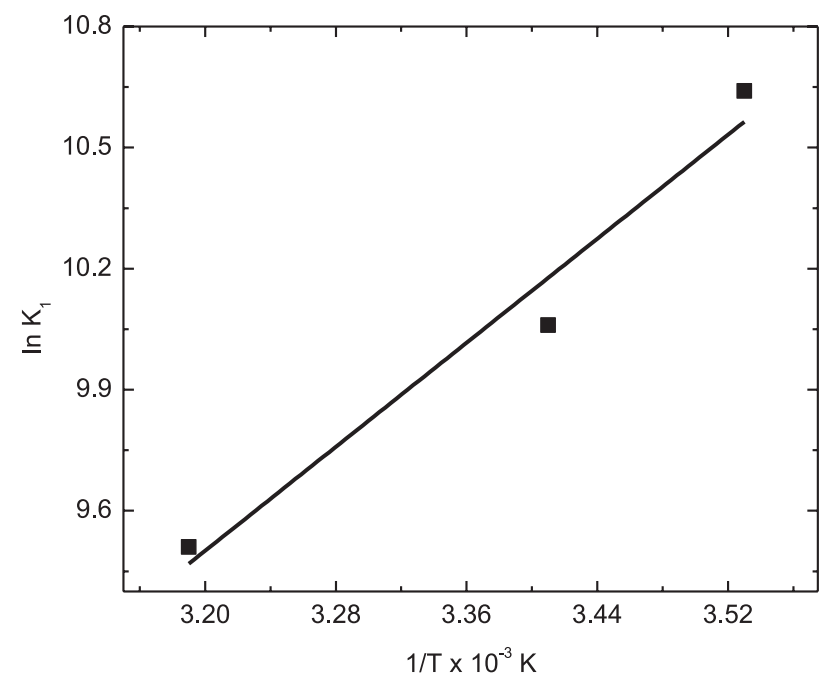

Fig. 7. Plot of $\operatorname{lnK}_{1}$ vs. $1 / \mathrm{T}$ for the adsorption of $\mathrm{AB} 129$ on Mg-bentonite clay. 
Table 3. Thermodynamic parameters for the adsorption of AB129 on Mg-bentonite at different temperatures.

\begin{tabular}{|c|c|c|c|c|c|c|}
\hline$T\left({ }^{\circ} \mathrm{C}\right)$ & $1 / T \times 10^{-3}\left(\mathrm{~K}^{-1}\right)$ & $\ln K_{1}$ & $\Delta H\left(\mathrm{~kJ} \mathrm{~mol}^{-1}\right)$ & $\Delta S\left(\mathrm{~kJ} \mathrm{~mol}^{-1} \mathrm{~K}^{-1}\right)$ & $\Delta G\left(\mathrm{~kJ} \mathrm{~mol}^{-1}\right)$ & $R^{2}$ \\
\hline 10 & 3.53 & 10.64 & & & -25.05 \\
\hline 20 & 3.41 & 10.06 & & -25.03 & -24.50 \\
\hline 30 & 3.30 & 9.168 & -31.83 & & -23.09 \\
\hline 40 & 3.19 & 9.510 & & & -24.74 \\
\hline
\end{tabular}

$$
\begin{gathered}
\Delta \mathrm{G}^{\circ}=-\mathrm{RT} \ln \mathrm{K}_{1} \\
\ln \mathrm{K}_{1}=-\frac{\Delta \mathrm{H}^{\circ}}{\mathrm{RT}}+\frac{\Delta \mathrm{S}^{\circ}}{\mathrm{R}}
\end{gathered}
$$

... where $\mathrm{R}$ is the ideal gas constant $\left(8.314 \mathrm{~J} \mathrm{~mol}^{-1} \mathrm{~K}^{-1}\right)$ and $\mathrm{T}$ is the absolute Temperature in kelvin. The values of $\Delta \mathrm{S}^{\circ}, \Delta \mathrm{G}^{\circ}$, and $\Delta \mathrm{H}^{\circ}$ are given in Table 3. The negative values of $\Delta \mathrm{G}^{\circ}-25.05,-24.50,-23.09$, and $-24.74 \mathrm{~kJ} \mathrm{~mol}^{-1}$ at 10,2030 , and $40^{\circ} \mathrm{C}$ show the spontaneous nature of the adsorption process. The values obtained for $\Delta \mathrm{G}^{\circ}$ are nearly constant, showing that there is no effect of temperature on the free energy of adsorption. The negative value $(-31.83$ $\mathrm{kJ} \mathrm{mol}^{-1}$ ) of $\Delta \mathrm{H}^{\circ}$ shows that the process of adsorption is exothermic in nature. Moreover, the values of $\Delta \mathrm{H}^{\circ}$ $\left(>-8 \mathrm{~kJ} \mathrm{~mol}^{-1}\right)$ verify that $\mathrm{AB} 129$ adsorption is a physical process [32]. The value of $\Delta \mathrm{S}^{\circ}$ is also negative because adsorption involves more order arrangement, or in other words disorderliness decreases, resulting in a decrease in entropy.

\section{Comparison of Adsorption Capacity}

of $\mathrm{Mg}$-Bentonite and $\mathrm{Ba}, \mathrm{Al}-$ Bentonite Clay

The bentonite clay was also treated with $\mathrm{Al}$ and $\mathrm{Ba}$ and their capacity was compared to $\mathrm{Mg}$-bentonite clay at the same experimental conditions. Fig. 8 demonstrates that $\mathrm{Mg}$-bentonite has better adsorption ability for the removal of AB129 from aqueous solution than $\mathrm{Ba}$ and $\mathrm{Al}$ bentonite, mainly because of its porous surface and small particle size. The SEM images in supplementary material explain

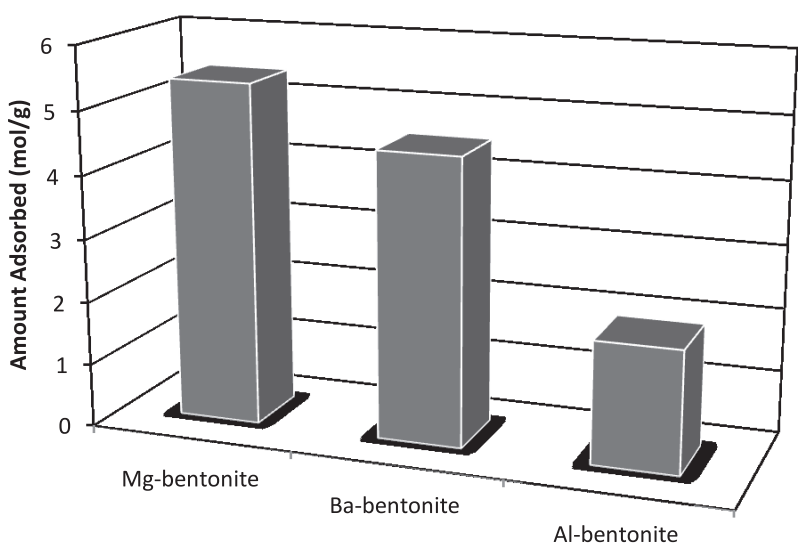

Fig. 8. Comparison of the adsorption capacity of Mg-bentonite with $\mathrm{Ba}$ and $\mathrm{Al}$-bentonite at $\mathrm{pH} 3$. the porosity and small particle size of Mg-bentonite. Natural bentonite is not a more effective adsorbent for the removal of hydrophobic organic compounds from aqueous solution, which is due to the electrically charged and hydrophilic characteristics of the surface. However, natural bentonite may be modified to improve its capability of removing hydrophobic contaminants from water.

\section{Conclusion}

The results demonstrate that naturally occurring clay bentonite has sufficient adsorptive properties and can be used as a promising adsorbent to remove AB129 dyes from an aqueous solution after chemical activation. The adsorption process was fast and equilibrium between AB129 in the solution and on the Mg-Bentonite surface was achieved in 40 minutes. Adsorption kinetics adequately obey the pseudo first-order model $\left(R_{2}>0.994\right)$. Adsorption isothermal studies reveal that the Freundlich model fits the experimental data well $\left(\mathrm{R}_{2}>0.996\right)$. The negative values of $\Delta \mathrm{G}^{\circ}$ showed that the adsorption process was spontaneous and physiosorptive. These results showed that AB 129 could be successfully removed from aqueous solution using Mg-bentonite clay as a cheap adsorbent.

\section{Acknowledgements}

The authors gratefully acknowledge the cooperation of lab technicians/assistant for the characterization of clay samples at the Centralized Recourse Laboratory (CRL) University of Peshawar, Pakistan.

\section{References}

1. KADIRVELU K., KAVIPRIYA M., KARTHIKA C., RADHIKA M., VENNILAMANI N., PATTABHI S. Utilization of various agricultural wastes for activated carbon preparation and application for the removal of dyes and metal ions from aqueous solutions. Bioresour. Technol. 87, 129, 2003.

2. WON S.W., CHOI S.B., YUN Y-S. On the reason why acid treatment of biomass enhances the biosorption capacity of cationic pollutants. Korean J. Chem. Eng. 31, 68, 2013.

3. ROBINSON T., CHANDRAN B., NIGAM P. Effect of pretreatments of three waste residues, wheat straw, corncobs and barley husks on dye adsorption. Bioresour. Technol. 85, 119, 2002. 
4. MitTAL A., THAKUR V., MitTAL J., VARDHAN H. Process development for the removal of hazardous anionic azo dye Congo red from wastewater by using hen feather as potential adsorbent. Desalin. Water Treat. 52, 227, 2014.

5. ZHANG J., CHEN S., ZHANG Y., QUAN X., ZHAO H., ZHANG Y. Reduction of acute toxicity and genotoxicity of dye effluent using Fenton-coagulation process. J. Hazard. Mater. 274, 198, 2014.

6. DE LUNA L.A.V., DA SILVA T.H.G., NOGUEIRA R.F.P., KUMMROW F., UMBUZEIRO G.A. Aquatic toxicity of dyes before and after photo-Fenton treatment. J. Hazard. Mater. 276, 332, 2014.

7. ALVES DE LIMA R.O., BAZO A.P., SALVADORI D.M.F., RECH C.M., DE PALMA OLIVEIRA D., DE ARAGÃO UMBUZEIRO G. Mutagenic and carcinogenic potential of a textile azo dye processing plant effluent that impacts a drinking water source. Mutat. Res. - Genet. Toxicol. Environ. Mutagen. 626, 53, 2007.

8. VERMA A.K., DASH R.R., BHUNIA P. A review on chemical coagulation/flocculation technologies for removal of colour from textile wastewaters. J. Environ. Manage. Jan 93, 154, 2012.

9. FERELLA F., DE MICHELIS I., ZERBINI C., VEGLIÒ F. Advanced treatment of industrial wastewater by membrane filtration and ozonization. Desalination. 313, 1, 2013.

10. ASGHAR A., ABDUL RAMAN A.A., WAN DAUD W.M.A. Advanced oxidation processes for in-situ production of hydrogen peroxide/hydroxyl radical for textile wastewater treatment: a review. J. Clean. Prod. 87, 826, 2015.

11. ZODI S., MERZOUK B., POTIER O., LAPICQUE F., LECLERC J.P. Direct red 81 dye removal by a continuous flow electrocoagulation/flotation reactor. Sep. Purif. Technol. 108, 215, 2013.

12. KURT E., KOSEOGLU-IMER D.Y., DIZGE N., CHELLAM S., KOYUNCU I. Pilot-scale evaluation of nanofiltration and reverse osmosis for process reuse of segregated textile dyewash wastewater. Desalination. 302, 24, 2012.

13. GOMES L., MIWA DOUGLAS W., MALPASS G.R.P, MOTHEO A.J. Electrochemical Degradation of the Dye Reactive Orange 16 using Electrochemical Flow-Cell. J. Brazilian Chem. Soc. 1, 2011.

14. CATANHO M., MALPASS G.R.P., MOTHEO A.J. Photoelectrochemical treatment of the dye reactive red 198 using DSA ${ }^{\circledR}$ electrodes. Appl. Catal. B Environ. Feb., 62, 193, 2006.

15. MITTAL J., THAKUR V., MITTAL A. Batch removal of hazardous azo dye Bismark Brown $\mathrm{R}$ using waste material hen feather. Ecol. Eng. Nov. 60, 249, 2013.

16. HUSSAIN S., GUL S., KHAN S., UR REHMAN H. Retention studies of chromium (VI) from aqueous solution on the surface of a novel carbonaceous material. Arab. J. Geosci. Nov; 6, 4547, 2012.

17. MITTAL A., KURUP L.. Column operations for the removal and recovery of a hazardous dye "acid red - 27" from aqueous solutions, using waste rnateria!s - bottom ash and de-oiled soya. Ecol. Environ. Conserv. 12, 181, 2006.
18. GUPTA V.K., MITTAL A., JAIN R., MATHUR M., SIKARWAR S. Adsorption of Safranin-T from wastewater using waste materials- activated carbon and activated rice husks. J. Colloid Interface Sci. 303, 80, 2006.

19. SANTOS S.C.R., BOAVENTURA R.A.R. Adsorption modelling of textile dyes by sepiolite. Appl. Clay Sci. 42, 137, 2008.

20. GUPTA V.K., MITTAL A., KURUP L., MITTAL J. Adsorption of a hazardous dye, erythrosine, over hen feathers. J. Colloid Interface Sci. 304, 52, 2006.

21. GHAEDI M., NASAB A.G., KHODADOUST S., SAHRAEI R., DANESHFAR A. Characterization of zinc oxide nanorods loaded on activated carbon as cheap and efficient adsorbent for removal of methylene blue. J. Ind. Eng. Chem. 21, 986, 2015.

22. ALVER E., METIN A. ü. Anionic dye removal from aqueous solutions using modified zeolite: Adsorption kinetics and isotherm studies. Chem. Eng. J. 200-202, 59, 2012.

23. SHARMA P., BORAH D.J., DAS P., DAS M.R. Cationic and anionic dye removal from aqueous solution using montmorillonite clay: evaluation of adsorption parameters and mechanism. Desalin. Water Treat. 1, 2015.

24. BHATTACHARYYA K.G., GUPTA S. SEN, SARMA G.K. Kinetics, equilibrium isotherms and thermodynamics of adsorption of Congo red onto natural and acid-treated kaolinite and montmorillonite. Desalin. Water Treat. 53, 530, 2013.

25. CHAARI I., FEKI M., MEDHIOUB M., BOUZID J., FAKHFAKH E., JAMOUSSI F. Adsorption of a textile dye "Indanthrene Blue RS (C.I. Vat Blue 4)" from aqueous solutions onto smectite-rich clayey rock. J. Hazard. Mater. 172, 1623, 2009.

26. ANIRUDHAN T.S., RAMACHANDRAN M. Adsorptive removal of basic dyes from aqueous solutions by surfactant modified bentonite clay (organoclay): Kinetic and competitive adsorption isotherm. Process Saf. Environ. Prot. 95, 215, 2015.

27. WANG C.C., JUANG L.C., HSU T.C., LEE C.K., LEE J.F., HUANG F.C. Adsorption of basic dyes onto montmorillonite. J. Colloid Interface Sci. 273, 80, 2004.

28. VELDE B. Introduction to clay minerals. Springer Netherlands; 1992.

29. SHEN Y-H. Preparations of organobentonite using nonionic surfactants. Chemosphere. Aug; 44, 989, 2001.

30. MITTAL A., GUPTA V.K. Adsorptive removal and recovery of the azo dye Eriochrome Black T. Toxicol. Environ. Chem. 1813, 2010.

31. HUSSAIN S., GUL S., KHAN S., REHMAN H., ISHAQ M., KHAN A., JAN F.A., DIN ZU. Removal of Cr(VI) from aqueous solution using brick kiln chimney waste as adsorbent. Desalin. Water Treat. Sep; 1, 2013.

32. REHMAN M.S.U., MUNIR M., ASHFAQ M., RASHID N., NAZAR M.F., DANISH M., HAN J-I. Adsorption of Brilliant Green dye from aqueous solution onto red clay. Chem. Eng. J. Jul; 228, 54, 2013. 